\title{
IgG INTRATHECAL SYNTHESIS AND SPECIFIC ANTIBODY INDEX IN PATIENTS WITH NEUROCYSTICERCOSIS
}

\author{
Luís R. Machado1, José A. Livramento1, Adelaide J. Vaz², Ednéia C. Bueno², \\ Sylvia R. Mielli', Vitória Bastouly', José Paulo S. Nóbrega ${ }^{1}$
}

ABSTRACT - We analyzed cerebrospinal fluid (CSF) and blood serum from 55 patients with neurocysticercosis (NC) at different clinical stages. According to inflammatory activity in the CSF, three stages were identified: (1) reactive, when there was at least an increase in the number of cells; (2) weakly reactive, when significant alterations were found in the CSF, including an increase in gamma globulins, albeit without hypercytosis; (3) non-reactive, when there was neither hypercytosis nor increase in gamma globulins. Nineteen patients had the reactive form; 18 had the weakly reactive form; 18 displayed the non-reactive form. Local immunoproduction was intense in the reactive group, moderate in the weakly reactive group, and absent in the non-reactive group. The specific antibody index was raised in approximately $2 / 3$ of patients with the reactive form, $2 / 3$ in those with the weakly reactive form, and $1 / 3$ in those with the non-reactive form. In conclusion: (1) the classical CSF syndrome in NC can present both in complete and partial modes; (2) local immunoproduction can occur in weakly reactive forms; (3) a raised specific antibody index can occur in the absence of an inflammatory reaction in the CSF.

KEY WORDS: neurocysticercosis, cysticercosis, cerebrospinal fluid, IgG, ELISA, passive hemagglutination, intrathecal synthesis, oligoclonal bands, specific antibody index.

\begin{abstract}
Síntese intratecal de lgG e índice de anticorpos específicos em pacientes com neurocisticercose
RESUMO - Analisamos o líquido cefalorraqueano (LCR) e o soro sanguíneo de 55 pacientes com neurocisticercose (NC) em diversas fases de evolução. De acordo com a atividade inflamatória no LCR, foram consideradas três formas: (1) reativa, quando havia pelo menos aumento do número de células; (2) fracamente reativa, quando havia alterações no LCR, incluindo aumento de globulinas gama, mas sem pleocitose; (3) não reativa, quando não havia pleocitose nem aumento de globulinas gama. Dezenove pacientes apresentavam a forma reativa, 18 a forma fracamente reativa, 18 a não reativa. 0 índice de anticorpos específicos estava aumentado em cerca de $2 / 3$ dos pacientes das formas reativa, em $2 / 3$ na forma fracamente reativa e em $1 / 3$ na forma não reativa. Conclusão: (1) a síndrome do LCR na NC pode apresentar-se tanto de modo completo quanto de modo parcial; (2) imunoprodução local de anticorpos específicos pode ocorrer também em pacientes sem aumento de células; (3) índice de anticorpos específicos elevado pode ocorrer mesmo na ausência de reação inflamatória no LCR.
\end{abstract}

PALAVRAS-CHAVE: neurocisticercose, cisticercose, líquido cefalorraqueano, IgG, ELISA, hemaglutinação passiva, síntese intratecal, bandas oligoclonais, índice de anticorpos específicos.

Neurocysticercosis (NC) results from Taenia solium larvae lodged in the central nervous system (CNS). Although it may remain asymptomatic or oligosymptomatic for long periods, NC is usually marked by relapses, in which clinical signs vary in intensity ${ }^{1,2}$. Diagnosis of NC is based on: clinical signs, neuroimaging (CT and MRI) and cerebrospinal fluid (CSF) ${ }^{3,4}$. CSF changes suggestive for NC were first descri- bed by Lange ${ }^{5}$ in 1940 . They are referred as the CSF syndrome of NC and include: (1) a mild or moderate increase in the number of cells with (2) presence of eosinophils, and (3) presence of anti-Taenia antibodies. New elements were added over following decades, without, however, altering the fundamental characteristics of this CSF syndrome. These changes are induced by parasite antigens and usually are more

\footnotetext{
${ }^{1}$ Department of Neurology, Faculty of Medicine, University of São Paulo, São Paulo SP, Brazil (USP); ${ }^{2}$ Laboratory of Clinical Immunology, Faculty of Pharmaceutical Sciences, USP.
}

Received 22 October 2001, received in final from 7 December 2001. Accepted 17 December 2001. 
apparent and more severe when affect the CSF space $^{6}$. CSF helps establish the etiological diagnosis (anti-Taenia antibodies immunoproduction) and determine whether the process is active (presence of the syndrome and immunoproduction of non-specific $\operatorname{lgGs})^{7-9}$. Regardeless clinical forms and neuroimaging findings, whether active or not, inflammatory changes proper to the CSF syndrome of NC can be detected and are diagnostic parameters ${ }^{1,3,10-15}$.

The objective of this study is to analyze prospectively the behavior of the diagnostic parameters and of the indicators of local inflammatory activity in NC patients, through comparative examination of the CSF and blood serum.

\section{METHOD}

We performed a prospective study of 55 patients from the Outpatient Ward for Infectious Diseases of the Nervous System at the São Paulo University Medical School Hospital. This project was approved by the Ethics Committee of the São Paulo University Medical School Hospital. All patients were amply informed as to their participation in the project, and signed the informed consent protocol. All the patients, with well defined clinical complaints, had prev diagnosis of NC confirmed by CSF examination and neuroimaging. We included patients by order of presentation. No restrictions were made as to clinical forms or stage of the disease.

Of the 55 patients, 32 were male $(58.2 \%), 39$ were white $(70.9 \%)$ and 16 brown or black $(29.1 \%)$. Their ages ranged from 15 to 72 years (average age: 41.9; median age: 42). Distribution by age and color was similar in all three groups. As to gender, men were predominant in the groups presenting the reactive form $(68.4 \%)$ and the weakly reactive form $(61.1 \%)$; however, in the non-reactive form, female patients predominated.

All patients were submitted to paired CSF and blood serum examination. The following data were considered: (1) for the CSF exam: pressure; number of cells; cytomorphological profile (with emphasis to the presence of neutrophils and eosinophils); glicose content; adenosine-deaminase (ADA) enzymme activity; (2) for the simultaneous CSF and blood serum test: total proteins; protein electrophoresis (isoelectrofocusing); albumin and IgG concentrations (nephelometry); presence of specific antibodies by: complement fixation test (CF), indirect immunofluorescence test (IFT), passive hemagglutination test (PHA), enzyme-linked immuno-sorbent assay (ELISA) and immunoblotting.

The Kölmer technique, modified by Spina-França ${ }^{10}$, was used for CF. IFT was processed following the technique of Camargo et al., modified by Livramento ${ }^{16,17}$. The PHA reaction was carried out in compliance with the technique of Ferreira et al. ${ }^{18}$. The ELISA reaction was processed in accordance with the technique of Costa et al. ${ }^{19}$. Immunoblotting was performed as per Vaz et al. ${ }^{20}$. IFT and immu- noblotting were used only as qualitative reactions.

The CSF/serum albumin quocient was used to evaluate the integrity of the CSF-blood barrier. To characterize local immunoproduction we used Link \& Tibbling IgG indices $^{21}$, Tourtellote's daily IgG synthesis ${ }^{22}$, Thompson's nomogram (IgG quotient versus albumin quocient) ${ }^{23,24}$ and protein isoelectrofocusing ${ }^{26}$. Anti-Taenia specific antibody indices were calculated by the method established by Reiber and Felgenhauer ${ }^{7}$, using an ELISA assay. This method was used to evaluate the ratio between CSF/serum quotient for specific antibodies and total IgG.

Three forms were considered, in accordance with the inflammatory activity recorded in the CSF examination: (1) a reactive form, when there was an increase in the number of cells, regardless of intensity, and regardless the occurrence of other CSF changes; (2) a weakly reactive form, when there were significant alterations in the CSF, including an increased gamma globulin content, albeit without hypercytosis; and (3) a non-reactive form, when there was neither hypercytosis nor an increased gamma globulin content, although mild isolated biochemical alterations could be found. Nineteen patients had the reactive form; 18 had the weakly reactive form; 18 had the non-reactive form.

Statistical analysis used the following tests: Chi-square (or Fisher's exact test), the Mann-Whitney $\mathrm{U}$ test, and the Krushkall-Wallis test. SPSS 7.5 for Windows was used for statistical study (SPSS Inc, Chicago, Illinois, USA). For the entire test, alpha $=0.05$ was established.

\section{RESULTS}

Table 1 shows the general data for the CSF. Hypertension is observed with similar frequency in all three groups studied. The other variables present significant fluctuation for the three groups. ADA activity levels are significantly raised in the reactive group patients.

Table 2 displays the rates of IgG alterations and IgG immunoproduction rates, as well as their respective $p$ values. Due to the classification criterion adopted, the frequency of alterations for all the variables analyzed was significantly different in the three groups $(p<0.0001)$. For this reason statistical comparison was only carried out for the reactive and weakly reactive forms.

Table 3 shows estimators and descriptive data for IgG and quantitative immunoproduction indices as well as the statistical comparison between the three groups considered. As with the results in Table 2, all variables presented significantly different results $(p<0.0001)$, owing to the classification criterion that was used. Therefore we consider $p$ values relating to the comparison between the 2 groups where there is an inflammatory reaction of the CSF.

Table 4 shows frequencies for specific reactant 
Table 1. General alterations in CSF from patients with neurocysticercosis (\%).

\begin{tabular}{lccccc}
\hline & $\begin{array}{c}\text { Reactive } \\
\text { form } \\
(\mathrm{n}=19)\end{array}$ & $\begin{array}{c}\text { Weakly } \\
\text { reactive } \\
\text { form } \\
(\mathrm{n}=18)\end{array}$ & $\begin{array}{c}\text { Non- } \\
\text { reactive } \\
\text { form } \\
(\mathrm{n}=18)\end{array}$ & $p$ & \\
\hline $\begin{array}{l}\text { CSF } \\
\text { hypertension }\end{array}$ & 21.1 & 33.3 & 22.2 & 0.72 & $\mathrm{NS}$ \\
$\begin{array}{l}\text { Hypercytosis* } \\
\begin{array}{l}\text { Neutrophils } \\
\text { Eosynophil }\end{array}\end{array}$ & 100 & 0 & 0 & $\mathrm{ND}$ & \\
cells & 52.6 & 11.1 & 0 & $<0.001$ & $\mathrm{~S}$ \\
$\begin{array}{l}\text { Total protein } \\
\text { increase }\end{array}$ & 84.2 & 55.6 & 27.8 & 0.003 & $\mathrm{~S}$ \\
$\begin{array}{l}\text { Glucose } \\
\text { decrease }\end{array}$ & 36.8 & 5.6 & 16.7 & 0.04 & $\mathrm{~S}$ \\
ADA increase & 73.7 & 5.6 & 0 & $<0.001$ & $\mathrm{~S}$ \\
\hline
\end{tabular}

*Statistical analysis not performed owing to the fact that this variable is a classification criterion.

immunological tests for cysticercosis, in the CSF and the blood serum. Table 5 shows the medians for the different immunological tests, as well as the $p$ and respective level of significance for CSF and serum.

Table 6 displays the specific antibody indices of Reiber and Felgenhauer, with regard to the frequency with which they were elevated and to the values of their medians. If we consider the frequency only in the reactive and weakly reactive groups, there was no statistically significant difference $(p=0.40)$. Considering the results case by case in the same groups, the values for specific antibody indices also showed no significant variation $(p=0.41)$.

\section{DISCUSSION}

The CSF syndrome of NC is expressed differently in the three groups: completely in the reactive group; partially in the weakly reactive group, and virtually absent in the non-reactive group (Tables 1 to 5). NC does not always present inflammatory changes in the $\mathrm{CSF}^{26,27}$, as can be seen in Table 1: (1) intracranial hypertension is observed with similar frequency in all three groups, suggesting the occurrence of the mass effect even in patients with the form that is non-reactive to the CSF exam; (2) an increase in proteins and a decrease in the glucose levels are observed, albeit less markedly, in significant percentages in the non-reactive group.

The inflammatory alterations in NC patients ( $\mathrm{Ta}$ -
Table 2. Increase in $\lg G$ and intrathecal synthesis in neurocysticercosis (\%)*.

\begin{tabular}{lcccc}
\hline & $\begin{array}{c}\text { Reactive } \\
\text { form } \\
(n=19)\end{array}$ & $\begin{array}{c}\text { Weakly } \\
\text { reactive } \\
\text { form } \\
(n=18)\end{array}$ & $p$ & \\
\hline IgG increase & 89.5 & 72.2 & 0.18 & NS \\
Oligoclonal bands & 47.4 & 5.6 & 0.004 & S \\
IgG index $>0.8$ & 73.7 & 55.6 & 0.25 & NS \\
$\begin{array}{l}\text { Tourtellotte daily } \\
\text { synthesis }>3.3\end{array}$ & 78.9 & 50.0 & 0.07 & NS \\
$\begin{array}{l}\text { Thompson } \\
\text { (intrathecal synthesis) }\end{array}$ & 52.6 & 22.2 & 0.06 & NS \\
\hline
\end{tabular}

* Owing to the classification criterion adopted, the non-reactive form is not considered for calculation of $p$; comparison is only between the reactive and weakly reactive forms.

Table 3. Values for IgG rates (CSF) and IgG intrathecal synthesis in neurocysticercosis (median).

\begin{tabular}{lccccc}
\hline & $\begin{array}{c}\text { Reactive } \\
\text { form } \\
(\mathrm{n}=19)\end{array}$ & $\begin{array}{c}\text { Weakly } \\
\text { reactive } \\
\text { form } \\
(\mathrm{n}=18)\end{array}$ & $\begin{array}{c}\text { Non- } \\
\text { reactive } \\
\text { form } \\
(\mathrm{n}=18)\end{array}$ & $p$ & \\
\hline IgG & 9.0 & 4.1 & 2.0 & 0.046 & $\mathrm{~S}$ \\
IgG index & 1.3 & 0.9 & 0.6 & 0.007 & $\mathrm{~S}$ \\
$\begin{array}{l}\text { Tourtellotte } \\
\text { daily synthesis }\end{array}$ & 27.1 & 3.4 & -3.4 & 0.005 & $\mathrm{~S}$ \\
\hline
\end{tabular}

Table 4. Specific IgG antibodies anti-Taenia (\%).

\begin{tabular}{|c|c|c|c|c|c|}
\hline & $\begin{array}{l}\text { Reactive } \\
\text { form } \\
(n=19)\end{array}$ & $\begin{array}{l}\text { Weakly } \\
\text { reactive } \\
\text { form } \\
(n=18)\end{array}$ & $\begin{array}{c}\text { Non- } \\
\text { reactive } \\
\text { form } \\
(n=18)\end{array}$ & $p$ & \\
\hline \multicolumn{6}{|l|}{ CSF } \\
\hline $\mathrm{CF}+$ & 57.9 & 11.1 & 0 & $<0.001$ & $S$ \\
\hline $\mathrm{IFT}+$ & 78.9 & 44.4 & 11.1 & $<0.001$ & $S$ \\
\hline $\mathrm{PHA}+$ & 84.2 & 88.9 & 61.1 & 0.10 & NS \\
\hline ELISA + & 94.7 & 83.3 & 38.9 & $<0.001$ & $S$ \\
\hline Immunoblot + & +94.7 & 88.9 & 55.6 & 0.006 & $S$ \\
\hline \multicolumn{6}{|l|}{ Serum } \\
\hline $\mathrm{CF}+$ & 36.8 & 27.8 & 16.7 & 0.39 & NS \\
\hline $\mathrm{IFT}+$ & 84.2 & 61.1 & 55.6 & 0.14 & NS \\
\hline $\mathrm{PHA}+$ & 94.7 & 66.7 & 55.6 & 0.02 & $S$ \\
\hline ELISA + & 94.7 & 83.3 & 55.6 & 0.01 & $S$ \\
\hline Immunoblot + & +94.7 & 72.2 & 27.8 & $<0.001$ & $\mathrm{~S}$ \\
\hline
\end{tabular}


Table 5. Specific IgG antibodies to cysticercosis (median).

\begin{tabular}{lccccc}
\hline & $\begin{array}{c}\text { Reactive } \\
\text { form } \\
(n=19)\end{array}$ & $\begin{array}{c}\text { Weakly } \\
\text { reactive } \\
\text { form } \\
(n=18)\end{array}$ & $\begin{array}{c}\text { Non- } \\
\text { reactive } \\
\text { form } \\
(n=18)\end{array}$ & $p$ & \\
\hline CSF & & & & & \\
CF & 1.0 & 0 & 0 & $<0.001$ & S \\
PHA & $1 / 128$ & $1 / 24$ & $1 / 4$ & $<0.001$ & S \\
ELISA & 111.0 & 54.0 & 0 & $<0.001$ & S \\
serum & & & & & \\
CF & 0 & 0 & 0 & 0.21 & NS \\
PHA & $1 / 320$ & $1 / 60$ & $1 / 40$ & $<0.001$ & S \\
ELISA & 50.0 & 19.0 & 8.0 & $<0.001$ & S \\
\hline
\end{tabular}

Table 6. Reiber \& Felgenhauer antibody index in patients with neurocysticercosis.

\begin{tabular}{lccccc}
\hline & $\begin{array}{c}\text { Reactive } \\
\text { form } \\
(\mathrm{n}=19)\end{array}$ & $\begin{array}{c}\text { Weakly } \\
\text { reactive } \\
\text { form } \\
(\mathrm{n}=18)\end{array}$ & $\begin{array}{c}\text { Non- } \\
\text { reactive } \\
\text { form } \\
(\mathrm{n}=18)\end{array}$ & $p$ & \\
\hline Increased (\%) & 78.9 & 66.7 & 33.3 & 0.009 & $\mathrm{~S}$ \\
Median & 2.9 & 8.4 & 5.0 & 0.62 & NS \\
\hline
\end{tabular}

bles 2 and 3) present different behavior when one considers the frequency of alterations or of estimators relating to local IgG immunoproduction ${ }^{28}$. Oligoclonal bands occurred with significantly different frequency in the reactive and weakly reactive groups; the increase in IgG, the alterations in Thompson's nomogram and the increase in the quantitative immunoproduction indices occurred with similar frequency in the reactive and weakly reactive groups. The reactive and weakly reactive groups presented a statistically significant difference in IgG intrathecal synthesis estimators for all the variables analyzed. These findings allow us to affirm that, for the quantitative variables, the inflammatory reaction in the CSF of NC patients occurs more intensely in the reactive forms, although the rate is similar for both groups. However, oligoclonal bands occur more frequently in the reactive form.

Analyzing the results of the specific immunological reactions (Tables 4 and 5 ), the following facts are striking: (1) in the non-reactive form, the ELISA test is relatively less sensitive; (2) in the non-reactive form, PHA is reactant with a greater frequency than the other reactions. This suggests that PHA may present greater sensitivity than other reactions in the forms of NC that are not accompanied by inflammatory changes in the CSF; (3) immunological reactions for cysticercosis present a higher degree of sensitivity when used together ${ }^{11}$; the association of at least two reactions is important (PHA and ELISA); (4) when performed only on serum, immunological reactions have increased sensitivity ${ }^{29-31}$, but run the risk of presenting decreased specificity.

The index of Reiber and Felgenhauer specific antibodies enables the diagnosis of CNS involvement in a high percentage of patients. As is classically known, a high index is unrelated to the activity of the disease. Disease activity is, however, best characterized by the presence of a generalized inflammatory reaction and the presence of local immunorelease of IgG (quantitative and/or qualitative criteria). Owing to the fact that NC is a chronic disease with recurrent acute episodes, the antibodies studied are from the IgG class, although there may be alterations of antibodies from classes $\lg \mathrm{M}, \lg \mathrm{A}$ and $\operatorname{lgE}$. Actually, in the non-reactive form (in which there is no local immunoproduction), 1/3 of patients presented an increase in the index of specific antibodies. The numerical values of these indices are similar to those found in the reactive and weakly reactive forms of NC (Table 6).

Sotelo and subsequently Del Brutto's descriptions of the active and inactive forms of NC enable the formation of NC groups that may benefit and groups that may not benefit from specific treatment $\mathrm{t}^{4,12,14,15}$. The detection in the CSF of antigens released by the parasite contributes for this purpose and is an additional marker to the study and clarification of the parasite-host relationship, as our research group recently showed ${ }^{32}$. Also, the recognition of different modes of presentation of the inflammatory reaction of the CSF in NC patients aims, presented in this study, provides new information so as to supplement current criteria in order to distinguish between the active and inactive forms of NC.

In conclusion: (1) it is possible to characterize variable expressivity in the classical CSF syndrome in NC patients, emphasizing either the diagnosis and/ or the activity of the disease. This enables delimitation of differentiated at-risk groups among patients infected with NC; (2) in NC, local immunoproduction phenomena occur significantly even in forms whose CSF is weakly reactive; (3) an increase in specific antibody indices can be detected, and hence it is possible to establish the immunological diagnosis of the disease even when inflammatory alterations are not found in the CSF. 


\section{REFERENCES}

1. Canelas HM. Neurocisticercose: incidência, diagnóstico e formas clínicas. Arq Neuropsiquiatr 1962;20:1-16.

2. Livramento JA, Machado LR, Spina-França A. Immunobiology of neurocysticercosis. In Fejerman N, Chamoles NA (eds). New trends in pediatric neurology. Amsterdan: Elsevier, 1993:307-312.

3. Machado LR, Nóbrega JPS , Barros NG, Livramento JA, Bacheschi LA, Spina-França A. Computed tomography in neurocysticercosis. A 10 year long evolution analysis of 100 patients with an appraisal of a new classification. Arq Neuropsiquiatr 1990;48:414-418.

4. Del Brutto OH, Sotelo J, Roman GC. Therapy for neurocystiercosis: a reappraisal. Clin Infec Dis 1993;17:730-735.

5. Lange O. Síndrome liquórico da cisticercose encéfalo-meningéia. Rev Neurol Psiquiatr São Paulo 1940;6:35-48.

6. Flisser A, Rivera L, Trueba J, et al. Immunology of human cysticercosis. In Flisser A, Willms K, Laclette JP, Larralde C, Ridaura C, Beltrán F (eds). Cysticercosis: present state of knowledge and perspectives. New York: Academic Press, 1982:549-563.

7. Reiber H, Felgenhauer K. Protein transfer at the blood cerebrospinal fluid barrier and the quantification of the humoral immune response within central nervous system. Clin Chim Acta 1987;163:319-328.

8. Sindic CJM. The intrathecal synthesis of antibodies in infectious diseases of the central nervous system. In Machado LR, Livramento JA, Nóbrega JPS, Gomes HR, Spina França A (eds). Neuroinfecção-98. São Paulo: Clínica Neurológica HC-FMUSP, 1998:193-198.

9. Puccioni-Sohler M, Rios M, Bianco C, et al. An inverse correlation of HTLV-I viral load in CSF and intrathecal synthesis of HTLV-I antibodies in TSP/HAM. Neurology 1999;53:1335-1339.

10. Spina-França A, Livramento JA, Bacheschi LA, Garcia-Lopes P. Cerebrospinal fluid immunoglobulins in cysticercosis of the central nervous system. Arq Neuropsiquiatr 1976;34:40-45.

11. Spina-França A, Livramento JA, Machado L R. Cysticercosis of the central nervous system and cerebrospinal fluid. Arq Neuropsiquiatr 1993;51:16-20.

12. Sotelo J, Guerrero V, Rubio F. Neurocysticercosis: a new classification based on active and inactive forms. Arch Intern Med 1985;45:442-445.

13. Takayanagui OM, Jardim E. Aspectos clínicos da neurocisticercose. Análise de 500 casos. Arq Neuropsiquiatr 1983;41:50-63.

14. Del Brutto OH, Wadia NH, Dumas M, Cruz M, Tsang VCW, Schantz PM. Proposal of diagnostic criteria for human cysticercosis and neurocysticercosis. J Neurol Sci 1996;142:1-6.

15. Del Brutto $\mathrm{OH}$, Rajshekhar V, White Jr AC, et al. Proposed diagnostic criteria for neurocysticercosis. Neurology 2001;57:177-183.

16. Livramento JA. Contribuição de reações de imunofluorescência no líquido cefalorraqueano ao estudo da neurocisticercose. Arq Neuropsiquiatr 1981;39:261-278.

17. Vaz AJ, Nakamura PM, Barreto CC, Ferreira AW, Livramento JA, Machado ABB. Immunodiagnosis of human neurocysticercosis: use of heterologous antigenic particles (Cysticercus longicollis) in indirect immunofluorescence test. Ser Immun Infec Dis 1997;8:157-161.
18. Ferreira AP, Vaz AJ, Nakamura PM, Sasaki AT, Ferreira AW, Livramento JA. Hemagglutination test for the diagnosis of human neurocysticercosis: development of a stable reagent using homologous and heterologous antigens. Rev Inst Med Trop São Paulo 1997;39:29-33.

19. Costa JM, Ferreira AW, Makino MM, Camargo ME. Spinal fluid immnoenzymatic assay (ELISA) for neurocysticercosis. Rev Inst Med Trop São Paulo1982;24: 337-341.

20. Vaz AJ, Nunes CM, Piazza RMF, e al. Immunoblot with cerebrospinal fluid from patients with neurocysticercosis using antigen from cysticerci of Taenia solium and Taenia crassiceps. Am J Trop Med Hyg 1997;57:354-357.

21. Link H, Tibbling G. Principles of albumin and IgG analyses in neurological disorders: III Evaluation of IgG synthesis within the central nervous system in multiple sclerosis. Scand J Clin Lab Invest 1977;37:397-401.

22. Tourtellotte WW, Staugaitis SM, Walsh MJ, et al. The basis of intrablood-brain-barrier IgG synthesis. Ann Neurol 1985;17:21-27.

23. Thompson EJ. The CSF proteins: a biochemical approach. Amsterdam: Elsevier, 1988.

24. Thompson EJ, Riches PG, Kohn J. Antibody synthesis within the central nervous system: comparisons of CSF IgG indices and electrophoresis. J Clin Pathol 1983;36:312-315.

25. Laterre C, Sindic C. Oligoclonal bands in CSF: usefulness and limits. In Thompson EJ (ed). Advances in CSF protein research and diagnosis. Norwell: MTP Press, 1987:109-122.

26. Bueno EC, Vaz AJ, Machado LR, Livramento JA. Neurocysticercosis: detection of IgG, IgA and IgM antibodies in cerebrospinal fluid, serum and saliva samples by ELISA with Taenia solium and Taenia crassiceps antigens. Arq Neuropsiquiatr 2000;58:18-24.

27. Bueno EC, Vaz AJ, Machado LR, Livramento JA, Mielle S. Specific Taenia crassiceps and Taenia solium antigenic peptides for neurocysticercosis immunodiagnosis using serum samples. J Clin Microbiol 2000;38:146151.

28. Correa D, Dalma D, Espinoza B, Plancarte A, Rabiela MT, Madrazo I, Gorodezky C, Flisser A. Heterogeneity of humoral immune components in human cysticercosis. J Parasitol 1985;71:535-541.

29. Sarti E, Flisser A, Schantz PM, Gleizer M, Loya M, Plancarte A, Avila G, Allan J, Craig P, Bronfaman M, Wijeyaratne P. Development and evaluation of a health education intervention against Taenia solium in a rural community in Mexico. Am J Trop Med Hyg 1997;56:127-132.

30. Simac C, Michel P, Andriatsimahavandy A, Esterre P, Michault A. Use of enzyme-linked immunoelectrotransfer blot for the diagnosis and monitoring of neurocysticercosis. Parasitol Res 1995;81:132-136.

31. Diaz J F, Verastegui M, Gilman RH, Tsang VCW, Pilcher JB, Gallo C, Garcia HHTP, Montenegro T, Miranda E. The Cysticercosis working group in Peru. Immunodiagnosis of human cysticercosis (Taenia solium): a field comparison of an antibody-enzyme-linked immunosorbert assay (ELISA), an antigen-ELISA, and an enzyme-linked immunoelectrotransfer blot (EITB) assay in Peru. Am J Trop Med Hyg 1992;46:610-615.

32. Pardini AX, Vaz AJ, Machado LR, Livramento JA. Cysticercus antigens in cerebrospinal fluid samples from patients with neurocysticercosis. J Clin Microbiol 2001;39:3368-3372. 